\title{
Da informação à liberdade: um percurso de conhecimento
}

\author{
Jorge Borges* \\ Vicentina Ramires**
}

\section{Resumo}

O presente texto revisa a literatura sobre o estudo da informação, considerando-a, simultaneamente, produto e produtora do processo de disseminação do conhecimento. Além de apresentar o fluxo que se desenha entre o nascimento da informação e sua transformação em saber, o artigo inicia uma discussão sobre o conhecimento e sua ligação com a liberdade. Neste aspecto, o conceito de cidadania é apresentado, considerando-a uma conquista do indivíduo e um meio capaz de fazer com que a sociedade conceba seu próprio processo de desenvolvimento. Ao analisar as ideias exploradas pela pesquisa bibliográfica, propõe-se um novo olhar sobre os estudo dos meios de Comunicação, apontando a informação como a base para se alcançar objetivos prospectivos de liberdade.

Palavras chave: Comunicação. Informação. Conhecimento. Cidadania. Liberdade.

\section{From information to freedom: a knowledge route}

\section{Abstract}

This paper reviews the literature on the study of information, considering the information as the product and the producer during the process of knowledge dissemination. Besides presents the flow that is drawn between the birth of information and their transformation into knowledge. The paper begins a discussion about knowledge and his link with freedom. In this respect, the concept of citizenship is shown and considered an achievement of the individual and an

\footnotetext{
* Professor do Curso de Publicidade e Propaganda, Faculdade Boa Viagem, Recife-PE, Brasil. Mestre em Administração e Desenvolvimento Rural pela Universidade Federal Rural de Pernambuco - UFRPE. E-mail: jorgesb@uol.com.br ** Professora Adjunta nos Programas de Mestrado em História e de Mestrado em Administração e Desenvolvimento Rural da Universidade Federal Rural de Pernambuco-UFPE, Recife-PE, Brasil. Doutora em Linguística pela UFPE. E-mail: diretoria@dlch.ufrpe.br
}

Intercom - RBCC

São Paulo, v.35, n.2, p. 19-38, jul./dez. 2012 
way possible of make the community capable of make his development process. Analyzing the ideas explored by the bibliographic research, we propose a new perspective on the study of media, pointing to information as the basis for reaching prospective goals of freedom.

Keywords: Communication. Information. Knowledge. Citizenship. Freedom.

\section{De la información a la libertad: una vía hecha de conocimiento Resumen}

Este artículo revisa la literatura sobre los estudios de la información, considerando la información como producto y productor durante el proceso de difusión del conocimiento. Además de mostrar el flujo que se dibuja entre el nacimiento de la información e su transformación en el conocimiento, el trabajo se inicia una discusión sobre el conocimiento y su relación con la libertad. En este sentido, el concepto de ciudadanía se muestra, teniendo en cuenta que la ciudadanía es el logro de un individuo y un medio capaz de hacer que la sociedad encuentre su propio proceso de desarrollo. Mediante el análisis de las ideas exploradas en la literatura, se propone una nueva perspectiva en el estudio de los medios de comunicación, apuntando la información como base para alcanzar los objetivos futuros de la libertad.

Palabras clave: Comunicación. Información. Conocimiento. Ciudadanía. Libertad.

Introdução

"We do not live like animals, our cities are different from anthills or termitaries, our towers are not beehives. We construct with concepts, with ideas, we build with illusions, the imaginary, sudden awarenesses, representations and even recently via information"'.

Michel Serres, Genesis (2005, p. 125)

\footnotetext{
aso seja realizada uma pesquisa sobre palavras usadas corriqueiramente no século 21, talvez uma se sobressaia de maneira espantosa: desenvolvimento. Mesmo tendo partido esta suposição de uma abstração pessoal, seja na linguagem comum ou na literatura econômica, o termo assumiu um caráter ideológico que ultrapassa as diretrizes iniciais propostas pelo progresso.

${ }^{1}$ Nós não vivemos como animais, nossas cidades são diferentes dos formigueiros ou cupinzeiros, nossas torres não são colmeias. Construímos com conceitos, com ideias, nós criamos com ilusões, imaginário, percepções, representações e, mais recentemente, com informação.
} 
Apesar de o desenvolvimento econômico ser, em grande parte, ainda, abordado com uma atenção maior - justificada pela certeza e consolidação do capitalismo -, o presente trabalho tem sob seus refletores uma outra vertente do desenvolvimento.

Nas últimas décadas, quando outras discussões foram somadas às referentes ao crescimento da economia, chegou-se a um debate sobre um tipo de desenvolvimento mais amplo. Assim, a tríade sustentada pelos pilares econômicos, ambientais e sociais gerou o conceito de desenvolvimento global. Pela interdependência existente entre eles, ambos compartilham de igual valor na construção da sociedade.

Com o desejo de estudar a importância do pilar humano na sustentação dessa tríade, busca-se aqui iniciar uma análise sobre os fatores que levam à consolidação do desenvolvimento social. O que o impulsiona? É a busca por essa resposta que norteia o discurso maior.

Encurtando um caminho que será mais bem detalhado, ao passar pelos estudos de Comunicação, informação e conhecimento, chega-se às liberdades individuais e seu papel no desenvolvimento da sociedade.

Por meio de pesquisa bibliográfica, propõe-se um novo enfoque ao estudo dos meios informativos levando ao desenvolvimento via liberdade. Se a análise exploratória foca o aperfeiçoamento de ideias, o presente trabalho assume esta postura ao sugerir que a liberdade pode ser estimulada pelo acesso à informação.

\section{Informação para a liberdade}

Quando Schramm (1976, p.19) alertou que "o subdesenvolvimento não é apenas um conjunto de índices e taxas, mas também uma postura mental", o autor afirmava que o desenvolvimento poderia ser o reflexo de mudanças na população - mudanças estas de ordem psicológica e em favor das liberdades. Se o que se pretende alcançar com uma mudança na sociedade é a "preservação e a busca constante de equilíbrio" (FREITAS, 1992, p.15), onde se deve buscar o suporte necessário para chegar a este objetivo, senão na informação, fruto da Comunicação? 
O uso da Comunicação com estes fins prospectivos mostra-se a ferramenta mais eficiente - e talvez única - de promover o exercício da cidadania. Segundo Josaphat (2006, p.14), "a linguagem da mídia atinge, penetra e vai embebendo todo o ser humano. Os sentidos, a inteligência, a afetividade, a imaginação, sobretudo sua capacidade de amar e sonhar".

Seja por meio da leitura, da presença da luz ou das ondas sonoras das mídias, a sociedade vai se modificando. Aos poucos os indivíduos vão adquirindo consciências transformadoras, quando as suas realidades são confrontadas com suas necessidades, seus direitos e deveres são questionados, suas liberdades são desejadas e a mudança surge como única saída possível.

\section{Complexo ato de comunicar}

Muitas são as possibilidades de aplicação da palavra "Comunicação" em uma frase. Seja no meio acadêmico ou empresarial, o termo já se popularizou a tal ponto que passou a abarcar diversos conceitos.

Ao se questionar sobre a verdadeira definição, o objetivo e o processo que envolve a Comunicação, David K. Berlo volta-se à primeira definição do termo, quando estudado por Aristóteles. Este abordava a Comunicação - em verdade a retórica - como a procura de todos os meios disponíveis de persuasão. Embora tenha discutido sobre os possíveis objetivos do enunciador, para Aristóteles a Comunicação tinha como principal objetivo convencer os outros a pensarem de acordo com o seu ponto de vista.

Olhar a Comunicação sob este ângulo foi aceito até o final do século 18, "embora a ênfase se tivesse deslocado dos métodos de persuasão para o que houvesse de 'bom' em quem fala" (BERLO, 2003, p.8). Neste período, a retórica teve seu estudo dualizado para os campos da mente e da alma, cuja natureza era cognitiva ou emocional, respectivamente. Por este estudo,

[...] um dos objetivos da Comunicação era informativo - um apelo à mente.

$\mathrm{O}$ segundo era persuasivo - um apelo à alma, às emoções. $\mathrm{O}$ terceiro era $\mathrm{O}$ divertimento, e argumentava-se que poderíamos classificar as intenções do comunicador, e o material de apoio por ele usado, dentro dessas categorias (BERLO, 2003, p. 8). 
Apesar de ser até certo ponto aceita a divisão do processo comunicativo por estas três intenções - informativa, persuasiva e de entretenimento -, deve-se atentar para o fato de que tais intenções não ocorrem somente de maneira isolada, pois, pode-se, por exemplo, divertir informando ou persuadir divertindo.

Segundo Berlo (2003, p.9), é preciso perceber que todo uso da linguagem tem um caráter persuasivo. De uma maneira ou de outra, a Comunicação é uma tentativa de persuadir.

Ao dividir as intenções em informar-persuadir-divertir, tira-se o olhar sobre a complexa dinâmica que se estabelece na Comunicação e passa a focar tão somente na mensagem, se o enunciado tem esta ou aquela função. Porém, "é difícil olhar um conjunto de palavras e determinar se é informativo ou persuasivo, que efeito terá sobre o receptor, qual a intenção da fonte ao produzi-lo" (BERLO, 2003, p.10).

De acordo com o Dicionário de Comunicação (BARBOSA e RABAÇA, 2001, p.155), o termo pode ser aplicado de diversas maneiras, referindo-se à relação entre os seres humanos, entre estes e os animais e máquinas, entre as máquinas ou entre os animais.

Ruesch e Bateson também veem a Comunicação além da simples transmissão de informação de um ponto a outro. Para eles, a Comunicação não se resume à transmissão verbal e intencional das mensagens. $\mathrm{O}$ conceito abrange, acima de tudo, os processos pelos quais as pessoas exercem influência sobre as outras.

Esta perspectiva parte da premissa de que as ações que envolvem o processo possuem "aspectos comunicativos assim que são percebidos por um ser humano; implica, além disso, que tal percepção modifica a informação que o indivíduo possui e, por conseguinte, influencia esse indivíduo" (Ruesch e Bateson apud BARBOSA e RABAÇA, 2001, p.156).

Este conceito coloca a Comunicação como a responsável pela união entre os indivíduos. É a responsável por formar a sociedade coesa. Mesmo que a inteligência dê ao ser humano a capacidade de avançar nas diversas esferas do desenvolvimento, é na Comunicação que se encontram os meios necessários para transmitir os conhecimentos. Segundo Schramm (1976, p.101), durante o processo que envolve a Comunicação, estabelece a estrutura de 
comunidade, na qual informações, ideias e conhecimentos são compartilhados.

De acordo com a abordagem sociológica e o conceito do agir comunicativo, faz-se necessário que a sociologia estude as redes de interação estabelecidas em uma sociedade por meio das relações comunicativas, a "união na Comunicação de sujeitos opostos".

A Comunicação visa à intercompreensão e ao consenso. A crise da democracia se dá devido ao fato de que os dispositivos sociais, que deveriam facilitar as trocas e o desenvolvimento da racionalidade comunicativa, ganham autonomia ao serem administrados como 'abstrações reais', fazendo realmente circular a informação, mas entravando as relações comunicativas, isto é, as atividades de interpretação dos indivíduos e grupos sociais (Habermas apud BARBOSA e RABAÇA, 2001, p.159).

Bakhtin, seguindo o pensamento de Saussure, "parte do princípio de que a língua é um fato social cuja existência funda-se nas necessidades de Comunicação" (BRANDÃO, 2002, p.9). Nessa visão, o processo de Comunicação encontra na linguagem a ferramenta necessária para promover a interação social.

Ao dizer, o sujeito significa em condições determinadas, impelido, de um lado, pela língua e, de outro, pelo mundo, pela sua experiência, por fatos que reclamam sentidos, e também por sua memória discursiva, por um saber/ poder/dever dizer, em que os fatos fazem sentido por se inscreverem em formações discursivas que representam no discurso as injunções ideológicas (ORLANDI, 2000, p.53).

Assim, além do sistema linguístico oferecer os elementos necessários para que seja estabelecido o processo de Comunicação, "é também a partir dos fatores externos que o falante deverá proceder para determinar suas escolhas. Cada indivíduo faz parte de um grupo social e usa a língua em situações variadas para atingir diferentes objetivos" (MODESTO, 2006, p.40).

Após resumida extração do conceito de Comunicação, pode-se perceber que a ideia central valorizada por todos é que, sem o processo comunicativo, não há como transferir informação, gerar conhecimento, estabelecer cultura e modificar comportamento. De acordo com o pensamento de Daniel Bougnoux (2002, p.7), 
"em nenhum lugar e nem para ninguém existe A Comunicação. Esse termo abrange práticas demais, necessariamente díspares, indefinidamente abertas e incontáveis"2.

Parece prudente, então, seguir a sugestão de Devèze (2000, p.29) e considerar, para além das definições, que o objetivo maior do termo Comunicação é, talvez, o de "construir o argumento do artigo XI da Declaração dos direitos do homem e do cidadão: a livre Comunicação dos pensamentos e da opinião é um dos direitos mais precisos do homem".

\section{Comunicação enquanto processo}

O teórico da Comunicação rejeita a hipótese de que na natureza os acontecimentos e ingredientes ocorram separados dos demais acontecimentos. Alega que "não se pode falar em $\underline{o}$ começo ou $\underline{o}$ fim da Comunicação, nem dizer que determinada ideia veio de uma fonte específica, que a Comunicação ocorre apenas numa direção" (BERLO, 2003, p.24). Basta uma busca rápida ao dicionário e encontraremos a palavra "processo" associada a uma realização contínua, regularidade, evolução ou sequência.

Tal conceituação coloca o processo como algo dinâmico e sempre em evolução, não existindo, portanto, um ponto de partida e um ponto de chegada. Por não serem estáticos, os elementos influenciam-se entre si, fazendo do processo uma ação continuada. Ao afirmar que a novela influencia a sociedade, por exemplo, esquece-se de considerar o quanto a sociedade modifica a prosa literária que constrói a novela.

Para descrever esse processo interativo que ocorre durante a Comunicação, é preciso extrair-lhe o movimento por meio de uma fotografia. Da mesma forma que o que está impresso na foto não é o momento mas sim a representação do momento, o que define o processo da Comunicação é a paralização da dinâmica da ação.

Considerando o quadro que se desenha do processo de Comunicação, pode-se, então, analisar os elementos que o compõem.

\footnotetext{
${ }^{2}$ Nulle part ni pour personne n'existe LA communication. Ce terme recouvre trop de pratiques, nécessairement disparates, indéfiniment ouvertes et non dénombrables.
}

Intercom - RBCC

São Paulo, v.35, n.2, p. 19-38, jul./dez. 2012 
Independente da formatação assumida em seu estado final, a informação deve ser estruturada de modo que o sentido não seja fruto apenas daquilo que foi intencionado pela fonte, mas também pelo receptor. A informação apresenta-se, desta forma, como fruto de uma cointencionalidade.

Charaudeau (2008, p.77), ao elaborar uma "situação de Comunicação", traz um esquema onde são apresentados os sujeitos envolvidos no ato comunicativo (Figura 1). Nesse modelo, onde os espaços externo e interno representam ambientes de produção e interpretação reais e imaginários, o autor propõe que, embora existam um locutor e um receptor reais (EUc e TUi, respectivamente), a situação de Comunicação faz surgir mais um enunciador e um destinatário imaginários (EUe e TUd, respectivamente).

O locutor EUc (real) fabrica TUd, um destinatário ideal e adequado ao seu ato de enunciação já que, enquanto sujeito comunicante, EUc tem total domínio e é o iniciador do processo de produção. Já o receptor TUi (real) cria uma imagem de quem seria o enunciador, como uma hipótese no processo de interpretação em função de suas experiências pessoais, construindo assim o enunciador EUe. Existe, assim, uma situação criada, pensada pelos sujeitos envolvidos antes mesmo da projeção da fala.

Figura 1 - Representação do dispositivo da encenação da linguagem

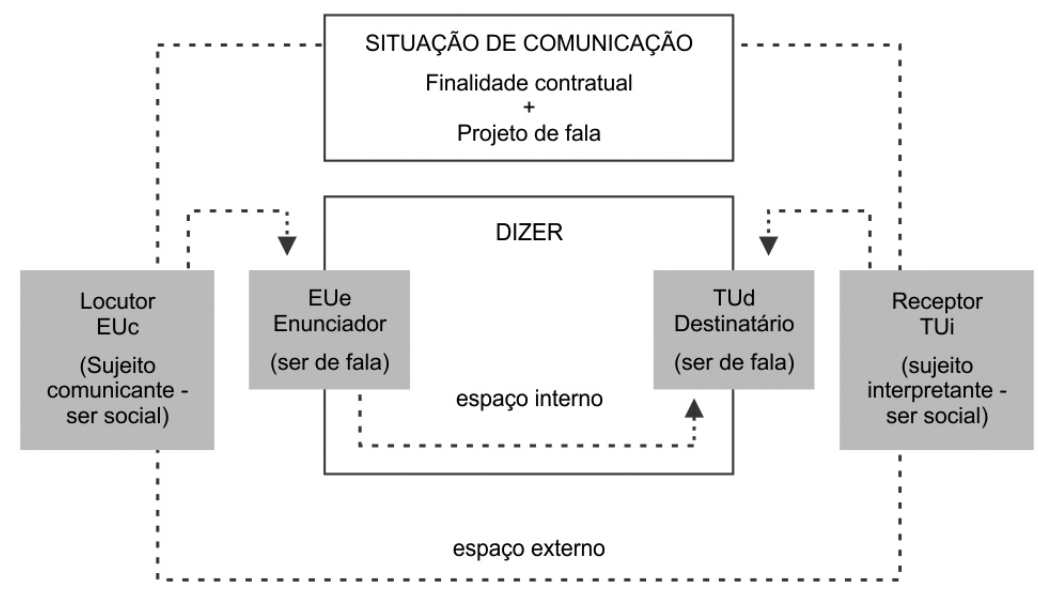

Fonte: CHARAUDEAU, 2008, p.77 
Para Bakhtin, a questão da intencionalidade como resultado final da compreensão da informação pelo receptor só terá êxito se a informação for percebida completamente. Para isso,

em cada enunciado [...] abrangemos, interpretamos, sentimos a intenção discursiva de discurso ou a vontade discursiva do falante, que determina o todo do enunciado, o seu volume e as suas fronteiras. Imaginamos o que o falante quer dizer, e com essa ideia verbalizada [...] é que medimos a conclusibilidade do enunciado (BAKHTIN, 2003, p. 281).

Assim, para que a Comunicação seja concretizada, é preciso que todos os elementos envolvidos no processo sejam retirados do campo da passividade e passem a ser analisados de acordo com sua relevância.

\section{Informação: produto e produtora}

Partindo da premissa de que a Comunicação é um processo e a informação é seu produto, constata-se que ela é, portanto, o terceiro ingrediente do ato de comunicar. Na retórica aristotélica, a informação é o que, o discurso pronunciado.

A informação não adquire sua forma senão por meio da atuação do ser humano. Ela não é como objetos materiais, que existem independentemente da ação do indivíduo.

Nos momentos de criação e assimilação da informação, acontece o que Barreto (2002, p.71) intitula de desenrolar ritualístico e constitui a essência da transferência da informação: "a (in)tensão da passagem e a solidão fundamental”. Na emissão da informação para o receptor,

o momento da intencionalidade aparece como o atributo de uma mensagem de informação ao ser propositadamente direcionada, de ser arbitrária para atingir seu destino; esse direcionamento intenso produz tensão, que é criada pela interação de competências distintas existentes nos diferentes mundos: o mundo do emissor da mensagem e o mundo de referências do receptor, colocado em sua realidade de convivência e para onde o conhecimento se destina (BARRETO, 2002, p.71).

No segundo momento, percebe-se a solidão fundamental, que expressa a condição do sujeito em relação a sua experiência vivenciada. 
Quando se vive uma vida pensante - que é o local onde se projeta a criação da informação antes de codificá-la -, isto acontece na mais escondida privacidade. Essa é a solidão fundamental de todos os que criam uma informação. É por meio da informação produzida, com a ajuda de um sistema de signos, que o homem procura relatar sua experiência vivenciada para outras pessoas; espalhar a outros sua experiência, que foi experimentada só por ele; que se processou no âmago de sua condição privada de criação individual e que se desloca para a esfera pública de uma significação, que se deseja, seja coletiva (BARRETO, 2002, p.71).

De acordo com estes dois momentos listados por Barreto, ao adquirir o conhecimento fruto do conteúdo informativo, ambas as partes (emissor e receptor), vivenciam uma passagem simbólica de solidão em mundos diferentes.

Durante esse percurso, a informação é considerada por Barreto (2002, p.71) uma cidadã de dois mundos. Durante estes momentos de passagem, vê-se o "fenômeno da informação apresentar sua característica mais bela, pois transcende ali a solidão fundamental do ser humano: o pensamento se faz informação e a informação se faz conhecimento".

\section{Conhecimento}

Sabendo que o conhecimento é adquirido por meio da informação, pode-se considerá-lo como a "elucidação da realidade e decorre de um esforço de investigação para descobrir aquilo que está oculto, que não está compreendido ainda" (MATOS, 2003). Portanto, só depois de descoberta a significação de alguma informação é que ela pode tornar-se conhecimento. $O$ conhecimento não está no acúmulo de informações, mas sim na utilização deste para descobrir algo novo o suficiente para fazê-lo avançar. "Quanto mais competente for o entendimento do mundo, mais satisfatória será a ação do sujeito que a detém" (MATOS, 2003).

Se para a informação engendrar conhecimento é preciso que sua significação seja clara, deve-se atentar não somente para o conteúdo da mensagem, mas também para a "escolha de efeitos de sentido para influenciar o outro, isto é [...] escolha de estratégia discursiva" (CHARAUDEAU, 2009, p.39). Esta preocupação 
é fundamental para que o conhecimento seja proveniente de um processo sólido o suficiente para transformá-lo em saber.

Para Barreto, ao assimilar uma informação, o indivíduo organiza estruturas mentais que geram o conhecimento. Desta forma, conhecer algo depende da interpretação individual dada às estruturas mentais construídas. A aquisição do conhecimento se dá pela reconstrução dessas estruturas mentais do indivíduo "realizado por meio de suas competências cognitivas, ou seja, é uma modificação em seu estoque mental de saber acumulado, resultante de uma interação com uma forma de informação" (BARRETO, 2002, p.72).

Essa reconstrução das estruturas mentais gera conhecimento pelo aumento e acúmulo do saber, por ratificar um saber já conhecido ou por modificar um saber anterior.

Com a ênfase na relação da informação e do conhecimento, modificou-se a importância relativa da gestão dos estoques de informação passando-se a apreciar a ação de informação na coletividade. Se antes havia uma razão prática e uma premissa técnica e produtivista para a administração e o controle dos estoques [de saber], agora a reflexão, o ensino e a pesquisa passaram a considerar as condições da melhor forma de passagem da informação para a realidade dos receptores; a promessa do conhecimento teria que considerar o indivíduo, seu bem-estar e suas competências para assenhorear-se da informação. E a premissa transformou-se em promessa (BARRETO, 2002, p. 72).

Este fluxo que se desenha entre o nascimento da informação e sua transformação em saber (Figura 2) inicia-se na associação da sensibilidade ao estoque de ideias e fatos que, transformados em informação, são transmitidos com o objetivo de gerar conhecimento. Este último, por sua vez, assimila-se à vida do receptor e torna-se inteligência, a qual é estocada na forma de saber (um acervo pessoal).

Para Barreto, a inteligência é a assimilação de um conhecimento na realidade do receptor e pode ser caracterizada como uma ação social, política, econômica ou técnica.

De acordo com Charaudeau, pretende-se com a informação transportar o indivíduo de um estado para outro: da ignorância para o saber, do desconhecido para o conhecido. O problema está no acesso a ela já que "não ter informação é não poder saber, logo, não poder informar" (2009, p.33). 
Figura 2 - Pirâmide de fluxos e estoques

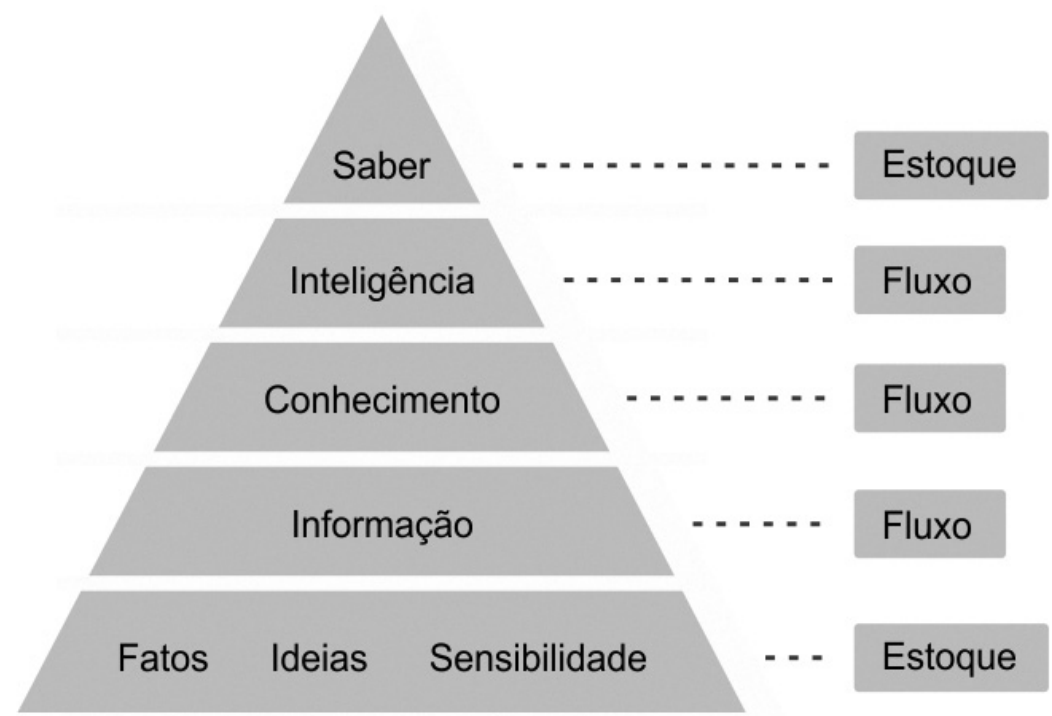

Fonte: BARRETO, 2002, p. 68

Levando a questão para a coletividade, pode-se afirmar que todo conhecimento é social, "pois é criação de um ser humano, histórico, fruto de determinada classe social, representante consciente ou inconsciente dos interesses provenientes da posição que o mesmo ocupa no processo produtivo" (ARAÚJO, 1992, p.74).

O propósito mais humano da Comunicação social encontra-se entre duas ações que obedecem a lógicas particulares. Segundo Charaudeau (2009, p.86), "uma visada de fazer saber, ou de informação propriamente dita; [...] uma visada de fazer sentir [...] que capta as massas para sobreviver à concorrência”. Esta última procura produzir o consumo seguindo uma lógica comercial. Já a visada de fazer saber busca formar o cidadão, levando-o a conhecer os fatos que ocorrem em sua vida social.

A partir do momento em que o indivíduo compreende a realidade que o cerca com base na informação que se lhe apresentam, ele adquire a conscientização essencial para promover qualquer mudança que se faça necessária. Por este motivo, os indivíduos que possuem o conhecimento verdadeiro de sua realidade não aceitam 
viver em condições subumanas, de opressão, de submissão e de privação de liberdades.

Para Araújo, a partir do momento que se adquire conhecimento de um estado de privação de liberdades, o indivíduo começa a buscar meios de promover a mudança. "O desejo de libertar-se de estruturas sociais, que não permitem viver uma vida verdadeiramente humana, é o passo principal no processo de conscientização do homem" (ARAÚJO, 1992, p.67-68).

Esta conscientização só é construída por meio do conhecimento. Ela não surge somente a partir da existência de problemas. Muitos vivem em condições de privação de liberdades sem ao menos se questionarem sobre suas realidades. É a falta de informação que leva à ausência de conhecimento e, consequentemente, também de conscientização.

Sob este aspecto, a sequência opressão - informação - conscientização - cidadania - liberdade leva o indivíduo aos "passos fundamentais na caminhada em direção à conquista de condições humanas de vida. Estes passos implicam um processo de busca por direitos, ou seja, de busca pela cidadania" (ARAÚJO, 1992, p.68).

\section{Informação e liberdade}

Ao dar ênfase ao processo de Comunicação sob o ângulo da informação para geração de conhecimento, encontra-se com as características que melhor definem sua natureza. Isto porque tais características estão associadas ao desenvolvimento do indivíduo e de suas liberdades.

Nesta perspectiva, a informação pode ser concebida como "instrumento modificador da consciência do homem. Quando adequadamente apropriada, produz conhecimento e modifica o estoque mental de saber do indivíduo" (BARRETO, 2002, p.70). Desta forma, a informação promove, além do bem-estar individual, o desenvolvimento da sociedade.

Como atingir o desenvolvimento se a sua matéria-prima lhe é negada ou omitida? A informação é a base para uma visão global com objetivos prospectivos, pois "conhecer a si mesmo, os outros e o ambiente permite o direcionamento adequado das ações com 
maiores possibilidades de resultados positivos [...] ou seja, maior liberdade de ação" (FACHINELLI e SATIE, 2000, p.223).

Por outro lado, a ausência de informação pode ser considerada uma das piores formas de privação de liberdade e de ditadura. Conforme Araújo (1992, p. 74), a partir do momento que a população se encontra desinformada, torna-se fácil exercer sobre ela uma relação de dominação começando a "criar distorções em suas demandas de modo que ela começa a buscar o favorecimento, o apadrinhamento e a manipulação".

$\mathrm{O}$ acesso e, principalmente, o direito à informação representam a síntese dos direitos sociais. A Organização das Nações Unidas (ONU) enfatiza isso ao destacar como fundamental o direito à informação, à Comunicação e à liberdade de expressão. Assim, afirma-se que o acesso à informação é um direito essencial para que o indivíduo tenha sua cidadania preservada.

Para melhor entender o significado e a grandeza do termo cidadania, percebe-se, na sua etimologia, que a palavra vem da noção de cidade. "Cidadão é o burguês, isto é, o habitante do burgo (cidade). Ser cidadão significa ser sujeito de direitos e deveres. Cidadão é aquele que está capacitado a participar da vida do burgo (cidade) e, consequentemente, da sociedade" (ARAÚJO, 1992, p.68).

Historicamente, o conceito concretiza-se com a revolução francesa (1789), através do princípio de liberdade, igualdade e fraternidade. Entretanto, este processo de concretização dos direitos do cidadão se dá junto ao advento do capitalismo que significou a constituição da sociedade burguesa, da sociedade cujo centro das decisões se localiza na cidade (ARAÚJO, 1992, p.68).

No modelo proposto por Rousseau, a cidadania é vista como "um direito coletivo que favorece a individualidade e que pressupõe ação política, e sua socialização implica na aquisição de direitos e no cumprimento de deveres em sociedade" (BATISTA, 2007 , p.5). Numa visão geral, a cidadania pode ser entendida como a expressão e o conjunto de direitos e deveres que os indivíduos possuem na sociedade.

Ao tratar de cidadania é preciso abranger a igualdade, a liberdade política e a democracia. Somente com estes três pilares solidificados pode-se abordar a cidadania em sua essência. 
Compreendemos cidadania, assim, como processo histórico de conquista popular, através do qual a sociedade adquire, progressivamente, condições de tornar-se sujeito histórico consciente e organizado, com capacidade de conceber e efetivar processo próprio. $O$ contrário significa a condição de massa de manobra, de periferia, de marginalização (DEMO, 1992, p.17).

Para inserir essa noção de cidadania, é preciso, primeiro, que os indivíduos tenham desenvolvido o conhecimento transformador. Caso contrário, tem-se o não-cidadão, o qual, "por estar coibido de tomar consciência crítica da manipulação que lhe é imposta, não atinge a oportunidade de conceber uma história alternativa e de organizar-se politicamente para tanto" (DEMO, 1995, p.2).

Berti (2008, p.230) aborda a necessidade de construção da cidadania pela promoção da autoestima, do poder e do senso de responsabilidade, sendo estes os pontos mais eficientes.

Peruzzo (2002) finaliza a questão da cidadania ressaltando cinco noções fundamentais.

Primeiro: o cidadão tem direitos e deveres. A participação política, a responsabilidade pelo conjunto da coletividade, o cumprimento das normas de interesse público são deveres, por exemplo. Segundo: a cidadania é histórica. Varia no tempo e no espaço, varia conforme o período histórico e o contexto vivido. Portanto, cabe sempre perguntar quem pode exercer plenamente a cidadania. Terceiro: a cidadania é sempre uma conquista do povo. A ampliação dos direitos de cidadania depende da "capacidade política" dos cidadãos, da qualidade participativa desenvolvida. Quarto: as formas de participação decorrem do tipo de sociedade política em que se vive. Quinto: a cidadania não se encerra nas suas dimensões da liberdade individual e participação política, mas inclui os direitos sociais e coletivos (PERUZZO, 2002).

A desigualdade na distribuição de informação entre indivíduos provoca, de acordo com Batista (2007, p.5), a concentração do poder nas mãos dos que detêm o conhecimento. "A conscientização e o reconhecimento dos direitos da pessoa como cidadão devem ser os primeiros passos nesse caminho de busca pela liberdade de escolhas e de oportunidades".

Caso ao longo desse caminho o exercício da cidadania seja desviado pela desigualdade no acesso à informação, surgirá, conforme já citado por Demo, a marginalização, a sociedade como massa de manobra. 
Aquele que desejar modelar essa massa conforme sua vontade o fará sem maiores esforços. Seja em proporções apocalípticas como Hitler modelou toda a Alemanha, ou em menor escala como a sociedade patriarcal modela as liberdades das mulheres nos pequenos vilarejos rurais. O poder conferido ao "possuidor da informação" e a consequente submissão do "desinformado" geram relações de desigualdade extrema. Estas não se referem somente à diferença no nível de conhecimento em si, mas também à desigualdade de todos os tipos de liberdades instrumentais estudadas pelo economista indiano Amartya Sen: liberdades políticas, facilidades econômicas, oportunidades sociais, garantias de transparência e segurança protetora.

Um exemplo oposto ao de opressão - e por isso mesmo de expansão da liberdade por meio da informação - foi a importância da imprensa no desenrolar da Revolução Francesa, quando "movimentos e partidos liberais vão se empenhar em abrir os caminhos para a liberdade [...] Será a força motriz das diferentes liberdades, sobretudo de pensamento e de opinião" (JOSAPHAT, 2006, p.54).

Assim, os meios de Comunicação são vistos como os maiores responsáveis pela promoção da ideologia ${ }^{3}$ de liberdade, pela valorização da responsabilidade do agente e pela busca constante do bem comum. Por meio desse entrosamento de corresponsabilidade e liberdade que se processa durante o ato de Comunicação, o indivíduo é promovido à categoria de sujeito. Para Freitas, "todo indivíduo humano, isto é, social, por sua vez, só tem existência histórica, só é agente de uma prática, sob a forma-sujeito que lhe é imposta pela ideologia”.

É preciso destacar que a informação midiática - para fins prospectivos de oferecer ferramentas para liberdade - deve transmitir ao indivíduo o material necessário para a construção do seu pensamento crítico e conversão em sujeito histórico, agente. Tais informações, embora pretendam convencer o receptor, precisam assumir uma postura opinativa "que não é uma crença sem

\footnotetext{
${ }^{3}$ Com base nas análises de Freitas (1992, p. 88-92) sobre os pensamentos de Althusser, a ideologia é um elemento universal da existência histórica e representa a relação imaginária entre os indivíduos e suas condições reais de existência. Para Althusser, não há prática senão e por uma ideologia e não há ideologia senão por e para sujeitos. A Ideologia interpela os indivíduos constituindo-os como sujeitos.
} 
consciência nem uma verdade pouco rigorosa, mas é a matéria de nossa vida cotidiana, o cimento de nossa adesão à vida e o fundamento de nossas escolhas essenciais" (BRETON, 2003, p.14-15).

A argumentação, neste caso, mesmo servindo de meio para fazer uma opinião ser partilhada, "se afasta tanto do exercício da violência persuasiva quando do recurso à sedução ou à demonstração científica" (BRETON, 2003, p.11). A informação cuja finalidade é gerar o saber e a liberdade deve ser dotada de argumentos que expressem a opinião do orador (verossímil) e localizam-se entre o convencimento retórico e o científico (Figura 3).

Figura 3 - Diferentes maneiras de convencer

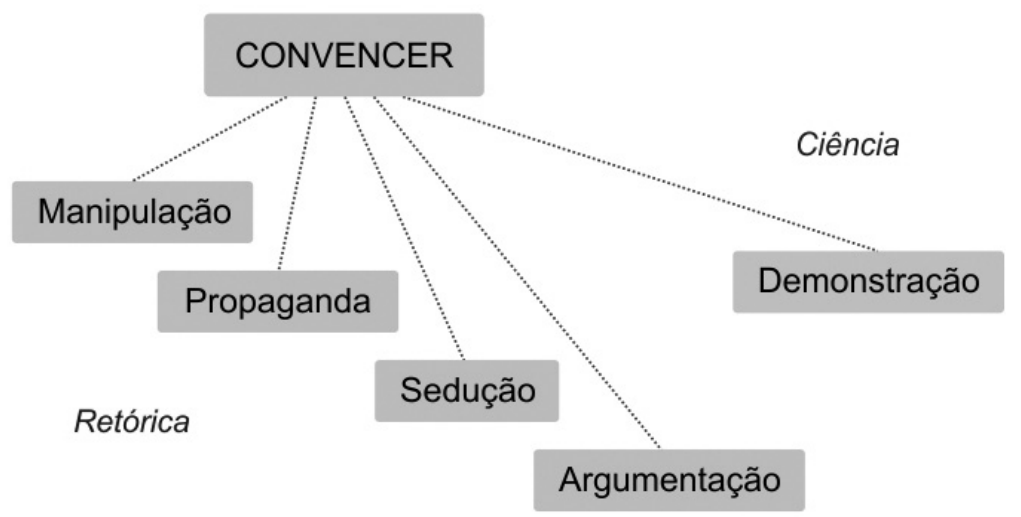

FONTE: BRETON, 2003, p. 10

De acordo com Josaphat (2006, p.46), a informação midiática "serve de referência à liberdade como valor regulador da vida social e [...] se afirma como cérebro e como voz da sociedade moderna". Por isso, o poder que é conferido aos meios de Comunicação pode sustentar a dinâmica de todas as outras esferas de poder ou pode ser usado como ferramenta de alienação que provoca o descarrilamento da máquina de poderes que sustenta a sociedade.

A liberdade é um valor em si, pois é a primeira qualidade do agir humano. Ela é a fonte dos outros valores, porque os membros da sociedade e essa própria sociedade sem a liberdade, especialmente sem a livre informação e a livre Comunicação das ideias, não poderão exercer os outros direitos e praticar diferentes deveres pessoais e sociais (JOSAPHAT, 2006, p. 80). 
É a conquista da liberdade e da cidadania que fazem uma sociedade organizada e consciente, apta a dar início ao seu próprio processo de desenvolvimento.

Assim, considerando o desenvolvimento um processo global que depende da capacidade de transformação de todos os indivíduos - independente de etnia, sexo, posição social ou qualquer outro fator discriminatório -, pode-se afirmar que somente por meio dos interesses individuais é possível chegar ao interesse maior para a sociedade. Se um indivíduo ou grupo não participar desse processo, suas vivências futuras sofrerão com privações e subordinações.

Da mesma forma que uma palavra só existe ao ganhar significação, o desejo de mudança só ocorre quando a realidade é conhecida. É preciso que o indivíduo compreenda e conheça suas situações vividas para que, a partir daí, busque a liberdade, ferramenta única para atingir a realização pessoal. Neste processo, em que o conhecimento mostra-se o principal combustível, a informação surge como força motriz para o desenvolvimento individual.

Se o desenvolvimento individual leva ao desenvolvimento da sociedade, aquele que tem tolhida sua participação neste processo irá apenas vivenciar o desenvolvimento que, na verdade, ocorreu pensado para outro. A título de simples ilustração, se for traçado um comparativo entre o processo de desenvolvimento e alguma vivência pessoal - como uma reunião de condomínio, por exemplo -, chega-se à importância de buscar sempre a condição de agente. Da mesma forma que só poderá participar aquele que estiver com o pagamento em dia e os faltantes deverão aceitar as decisões tomadas em sua ausência, no desenvolvimento, só aqueles que possuem o exercício de suas liberdades participam do processo e, quanto aos demais, estes acabam por vivenciar as deliberações que outros julgaram ideais. Estas geralmente só favorecem àqueles que participam ativamente.

Ao olhar para o caminho que leva ao desenvolvimento, parece claro que a via principal chama-se Liberdade. É ela que conduz os indivíduos ao seu destino final de realização. Somente ela proporciona, enquanto é percorrida, um estado de conhecimento de si mesmo, dos outros e da sociedade. Com um olhar mais atento enquanto caminha sobre a liberdade, pode-se observar que é cons- 
tituída de informações e dos saberes acumulados, fixados em sua superfície, e que lhe conferem um aspecto de solidez. Indo mais além em sua análise, conclui-se que a ferramenta mais adequada para bem construí-la é a Comunicação.

\section{Referências}

ARAÚJO. Eliany Alvarenga de. Informação, cidadania e sociedade no Brasil. Informação e sociedade: Estudos, João Pessoa, v. 2, n. 1, p. 67-77, 1992.

BAKHTIN, Mikhail. Estética da criação verbal. São Paulo: Martins Fontes, 2003.

BARRETO, Aldo. A condição da Informação. Revista São Paulo em perspectiva. São Paulo, Fundação Seade, v.16, n.3, p. 67-74, 2002.

BARBOSA, Gustavo e RABAÇA, Carlos Alberto. Dicionário de Comunicação. Rio de Janeiro: Campus, 2001.

BATISTA, Roseli Araújo. $\mathrm{O}$ acesso à informação como requisito para o exercício da cidadania. disponível em: http://www2.metodista.br/unesco/agora/mapa_animadores_pesquisadores_roseli.pdf. Acesso em: 6 set. 2010.

BERLO, David K. O processo de Comunicação: introdução à teoria e à prática. São Paulo: Martins Fontes, 2003.

BERTI, Orlando. A construção da cidadania rural pelas rádios comunitárias no sertão do nordeste brasileiro: o caso da FM comunitária terceiro milênio em Dom Expedido Lopes - PI. In: FUSER, Bruno (org.). Comunicação para a cidadania: caminhos e impasses. Rio de Janeiro: E-papers, 2008, p.227-245.

BOUGNOUX, Daniel. Introduction aux sciences de la communication. Paris: La Découverte, 2002.

BRANDÃO, Helena H. Nagamine. Introdução à análise do discurso. Campinas: Editora da UNICAMP, 2002.

BRETON, Philippe. A argumentação na Comunicação. Bauru: EDUSC, 2003.

CHARAUDEAU, Patrick. Linguagem e discurso: modos de organização. São Paulo: Contexto, 2008. . Discurso das mídias. São Paulo: Contexto, 2009.

Intercom - RBCC

São Paulo, v.35, n.2, p. 19-38, jul./dez. 2012 


\section{JORGE BORGES; VICENTINA RAMIRES}

DEMO, Pedro. Cidadania menor: algumas indicações quantitativas da nossa pobreza política. Petrópolis: Vozes, 1992.

DEVÈZE, Jean. As ciências da informação e da comunicação na França: no caminho de uma hermenêutica da troca humana e social. In: FRAU-MEIGS, Divida et al (Orgs.). Comunicação e informação: identidades e fronteiras. São Paulo: Intercom; Recife: Bagaço, 2000. p. 21-40.

FACHINELLI, Ana, SATIE, Carole. Comunicação, informação e desenvolvimento regional. In: FRAU-MEIGS, D. et al (Orgs.). Comunicação e informação: identidades e fronteiras. São Paulo: Intercom; Recife: Bagaço, 2000.

FREITAS, Jeanne Marie Machado de. Comunicação e psicanálise. São Paulo: Escuta, 1992.

JOSAPHAT, Frei Carlos. Ética e mídia: liberdade, responsabilidade e sistema. São Paulo: Paulinas, 2006.

MATOS, Cleusa M. Alves de. Conhecimento x informação: uma discussão necessária. Revista Espaço Acadêmico, Maringá, n. 31, dez. 2003. Disponível em: < http://www.espacoacademico.com.br/031/31 cmatos.htm >. Acesso em: 6 set. 2010.

MODESTO, Artarxerxes. Formas de tratamento no português brasileiro: a alternância tu/você na cidade de Santos. 2006. 141 f. Dissertação (Mestrado em Bens Culturais e Projetos Sociais). Fundação Getúlio Vargas, Rio de Janeiro, 2006.

ORLANDI, Eni Puccinelli. Análise de discurso: princípios e procedimentos. Campinas, SP: Pontes, 2000.

PERUZZO, Cicilia M. K. Comunicação comunitária e educação para a cidadania. Revista do Pensamento Comunicacional Latino Americano. São Bernardo do Campo: Cátedra UNESCO de Comunicação da UMESP/ALAIC, v. 4, n. 1, 2002. Disponível em < http://www2.metodista.br/unesco/PCLA/revista13/artigos\%2013-3.htm >. Acesso em: 8 set. 2010.

SCHARAMM, Wilbur. Comunicação de massa e desenvolvimento. Rio de Janeiro: Bloch, 1976.

SERRES, Michel. Genesis. Michigan: University of Michigan, 1995. 